\title{
PENERAPAN STRATEGI PEMBELAJARAN AKTIF TIPE TEAM QUIZ PADA MATA PELAJARAN SEJARAH TERHADAP PENINGKATAN KEAKTIFAN BELAJAR SISWA KELAS X IPS DI SMA NEGERI 8 BATAM TAHUN PELAJARAN 2018/2019
}

\section{THE APPLICATION OF ACTIVE LEARNING STRATEGIES TYPE TEAM QUIZ LESSON IN HISTORY AGAINST INCREASED ACTIVENESS LEARNING CLASS X SOCIAL SCIENCES IN SECONDARY SCHOOLS ON 8 BATAM IN THE ACADEMIC YEAR 2018/2019}

\author{
Desma Yulia ${ }^{1}$, Ratih Purnamasari ${ }^{2}$ \\ ${ }^{1,2}$ Program Studi Pendidikan Sejarah, Fakultas Keguruan dan Ilmu Pendidikan, Universitas Riau \\ Kepulauan, Indonesia \\ ${ }^{1}$ Desmayulia48@gmail.com, ${ }^{2}$ RatihPurnamasari1301@gmail.com
}

\begin{abstract}
Abstrak
Hasil penelitian menunjukkan bahwa melalui penerapan strategi pembelajaran aktif Team Quiz dalam pembelajaran sejarah dapat meningkatkan keaktifan belajar siswa dalam proses pembelajaran Sejarah. Peningkatan keaktifan siswa terbukti dengan diperoleh rata-rata keaktifan siswa dari total skor angket belajar siswa kelas eksperimen dengan total skor angket ( $\Sigma X)$ sebesar 4870, nilai terbesar siswa (Xmax) adalah 133 dan nilai terkecil (Xmin) adalah 93 dengan mean atau rata-rata $(\bar{x})$ sebesar 116.6. sedangkan pada kelas kontrol, total skor angket belajar yang diperoleh ( $\Sigma X)$ sebesar 4408, nilai terbesar siswa (Xmax) adalah 130 dan nilai terkecil (Xmin) adalah 83, dengan mean atau rata-rata $(\bar{x})$ sebesar 107.57.
\end{abstract}

Kata kunci : Strategi, PembelajaranAktif, Tipe Team Quiz, Keaktifan Siswa

\begin{abstract}
The results show that through the application of active learning strategies Quiz Team history teaching can improve students learning activeness in the learning process of History. Increased involvement of the student as evidenced by the average obtained from the student activity questionnaire total score grade students experiment with a total score of the questionnaire ( $\Sigma X)$ of 4870 , the largest value of students (Xmax) is 133 and the smallest value (xmin) is 93 with the mean or the mean average $(x)$ amounted to 116.6. while in the control group, the total score of the questionnaire study obtained $(\Sigma X)$ of 4408, the largest value of students (Xmax) is 130 and the smallest value (xmin) is 83, with the mean or average $(x)$ amounted to 107.57.
\end{abstract}

Keywords: Strategies, Active Learning, Type Team Quiz, activeness Students

\section{PENDAHULUAN}

Pendidikan pada hakikatnya merupakan usaha manusia untuk memanusiakan atau membudayakan manusia itu sendiri (Syafril, 2012: 36). Pendidikan merupakan 
Historia: Jurnal Program Studi Pendidikan Sejarah

Vol 4. No 1 (2019):34-45

P-ISSN 2301-8305

E-ISSN 2599-0063

proses pembangunan karakter dan pengembangan kepribadian peserta didik secara utuh.

Di dalam UU no. 20 Tahun 2003 tentang Sistem Pendidikan Nasional dijelaskan bahwa pendidikan nasional berfungsi mengembangkan kemampuan dan membentuk watak serta peradaban bangsa yang bermartabat dalam rangka mencerdaskan kehidupan bangsa, bertujuan untuk mengembangkan potensi peserta didik agar menjadi manusia yang beriman dan bertaqwa kepada Tuhan Yang Maha Esa, berakhlak mulia, sehat, berilmu, cakap, kreatif, mandiri, dan menjadi warga negara yang demokratis serta bertanggung jawab (http://suaidinmath.files.wordpress.com/2014/09/5-pmp-sejin-smaallson-1juni2014.docx diunduh tanggal 6 maret 2016).

Istilah pendidikan erat kaitannya dengan kurikulum. Kurikulum diartikan sebagai suatu komponen yang memiliki peran penting dalam sistem pendidikan, sebab dalam kurikulum bukan hanya dirumuskan tentang tujuan yang harus dicapai sehingga memperjelas arah pendidikan akan tetapi juga memberikan pemahaman tentang pengalaman belajar yang harus dimiliki setiap siswa (Sanjaya, 2008: v). Hal ini sesuai dengan rumusan undang-undang No.20 Tahun 2003 tentang sistem pendidikan nasional, kurikulum adalah seperangkat rencana dan pengaturan mengenai tujuan, isi dan bahan pelajaran serta cara yang digunakan sebagai pedoman penyelenggaraan kegiatan pembelajaran untuk mencapai pendidikan tertentu (Muzamiroh, 2013: 19).

Dalam rangka mengimplementasikan Kurikulum 2013 tersebut memerlukan keterlibatan berbagai komponen. Salah satu komponen yang sangat penting adalah guru. Bahkan guru dikatakan sebagai ujung tombak dan pasukan terdepan dalam upaya mencapai tujuan pendidikan nasional. Dalam konteks pendidikan formal guru adalah 
Historia: Jurnal Program Studi Pendidikan Sejarah

Vol 4. No 1 (2019):34-45

P-ISSN 2301-8305

E-ISSN 2599-0063

komponen yang pertama kali bersentuhan langsung dengan peserta didik dalam proses pendidikan melalui berbagai kegiatan pembelajaran di kelas (Muzamiroh, 2013: 121).

Berdasarkan hasil pengamatan penulis melihat bahwa ada beberapa permasalahan yang terdapat pada siswa kelas X IPS di SMA Negeri 8 Batam yaitu siswa kurang aktif dalam proses belajar mengajar yang ditandai dengan, banyak siswa yang tidak meperhatikan jalannya diskusi serta kurangnya respon terhadap diskusi ditandai dengan tidak adanya siswa yang bertanya maupun menyampaikan kritik atau masukan terhadap hasil diskusi. Suasana belajar di kelas menjadi monoton dan kurang menarik. Siswa yang tidak mengetahui materi cenderung diam dan tidak bertanya sehingga proses pembelajaran hanya berjalan satu arah. Selain itu, sikap tanggungjawab juga masih kurang pada diri siswa. Hal ini dapat dilihat dari setiap diberikan tugas, siswa masih banyak yang tidak mengerjakan dan tidak mengumpulkan tugas dengan tepat waktu.

Berdasarkan masalah tersebut peneliti meyimpulkan bahwa masalah yang terdapat di SMA Negeri 8 Batam yaitu kurangnya keaktifan siswa dalam kegiatan pembelajaran terutama penekanan kepada aspek afektif, yang dapat dilihat dari banyak siswa yang tidak perduli, kurang respon, tidak memperhatikan jalannya diskusi, serta kurangnya sikap tanggung jawab dan disiplin dalam mengerjakan dan mengumpulkan tugas tepat waktu. Mempertimbangkan masalah tersebut maka penulis melakukan penelitian dengan judul penerapan strategi pembelajaran aktif tipe Team Quiz pada mata pelajaran Sejarah terhadap peningkatan keaktifan belajar siswa kelas X IPS di SMA Negeri 8 Batam tahun pelajaran 2018/2019. Silberman (2013: 175) menjelaskan bahwa Team Quiz melatih siswa untuk belajar dengan cara bekerjasama sehingga 
meningkatkan kemampuan tanggung jawab siswa terhadap materi yang dipelajari dengan cara yang menyenangkan. Proses belajar mengajar dengan strategi pemebelajaran aktif Team Quiz mengajak siswa melakukan diskusi, bertanya, menjawab pertanyaan, memberi arahan, mengemukakan pendapat, dan menyampaikan informasi dengan cara bekerjasama dengan tim.

Team Quiz (kuis Kelompok) yaitu suatu strategi yang bermaksud untuk meningkatkan keaktifan siswa dalam proses belajar. Team quiz adalah salah satu tipe dari Active learning. Team Quiz meningkatkan kemampuan tanggung jawab peserta didik terhadap apa yang mereka pelajari melalui cara yang menyenangkan dan tidak menakutkan. Proses belajar mengajar dengan strategi Team Quiz mengajak siswa bekerjasama dengan timnya dalam melakukan diskusi, bertanya, menjawab pertanyaan, memberi arahan, mengemukakan pendapat, serta menyampaikan informasi. Silberman (2013: 175) prosedur Team Quiz adalah sebagai berikut:

1) Guru memilih topik yang dapat dipresentasikan dalam beberapa bagian.

2) Siswa membentuk tim belajar dan masing-masing tim akan mendapatkan tugas untuk membahas satu bagian dari topik yang telah ditentukan.

3) Guru menjelaskan aturan main atau format pelajaran Team Quiz dan mulai melakuikan presentasi dengan batasan waktu yang telah ditentukan.

4) Diskusi dimulai dan tim pertama menyiapkan kuis jawaban singkat tentang topik yang dibahas sementara tim lain menyiapkan diri dan memeriksa catatan mereka.

5) Kuis dimulai dengan tim pertama sebagai pemimpin kuis, tim pertama memberikan pertanyaan kepada tim kedua. Jika tim tersebut tidak dapat 
Historia: Jurnal Program Studi Pendidikan Sejarah

Vol 4. No 1 (2019):34-45

P-ISSN 2301-8305

E-ISSN 2599-0063

menjawab, tim ketiga dan seterusnya diberi kesempatan untuk segera menjawab.

6) Tim pertama melanjutkan kuis dengan memberikan pertanyaan selanjutnya kepada tim kedua lalu ulangi prosesnya secara bergantian.

7) Ketika kuis selesai, dilanjutkan ke bagian kedua kuis dengan memanggil tim kedua sebagai pemimpin kuis proses ini diulangi seperti pada kuis bagian pertama.

8) Begitu seterusnya hingga semua tim mendapat giliran.

\section{METODE PENELITIAN}

Penelitian ini merupakan penelitian kuantitatif karena dalam penelitian kuantitatif menekankan pengujian teori melalui pengukuran variabel penelitian dengan angka dan melakukan analisis data dengan prosedur statistik (Rumengan, 2009: 19). Pendekatan yang digunakan dalam penelitian ini adalah quasi eksperimen atau eksperimen semu.

Desain yang digunakan dalam penelitian ini adalah Posttest Only Control Group Design, dalam desain ini ada dua kelompok yang dipilih secara random. Kelompok pertama diberi perlakuan dengan menggunakan strategi Team Quiz sedangkan kelompok kedua tidak diberikan perlakuan atau menggunakan metode konvensional. Teknik sampling dalam penelitian ini menggunakan probability sampling yaitu dengan menggunakan simpel random sampling atau metode acak sederhana.

Variabel penelitian pada dasarnya adalah segala sesuatu yang berbentuk apa saja yang ditetapkan oleh peneliti untuk dipelajari sehingga diperoleh informasi tentang hal tersebut, kemudian ditarik kesimpulannya (Sugiyono, 2013: 38). Penelitian ini 
Historia: Jurnal Program Studi Pendidikan Sejarah

Vol 4. No 1 (2019):34-45

P-ISSN 2301-8305

E-ISSN 2599-0063

menggunakan dua variabel yaitu variabel bebas (independent variable) dan variabel terikat (dependent variable).Variabel bebas (independent variable), adalah variabel yang mempengaruhi atau yang menjadi sebab perubahan atau timbulnya variabel dependen atau terikat (Sugiyono, 2013: 39). Variabel bebas penelitian ini adalah pembelajaran dengan menerapkan strategi pembelajaran aktif tipe Team Quiz. Variabel terikat (dependent variable), adalah variabel yang dipengaruhi atau yang menjadi akibat karena adanya variabel bebas. Variabel terikat dalam penelitian ini yaitu keaktifan belajar siswa pada mata pelajaran Sejarah di SMA Negeri 8 Batam.

\section{PEMBAHASAN}

Populasi dalam penelitian ini adalah siswa kelas X IPS. Dalam pengambilan sampel pada penelitian ini menggunakan teknik sampling yaitu Simple random sampling atau acak sederhana. Sampel yang terpilih adalah kelas X IPS 1 sebagai kelas eksperimen dengan jumlah siswa sebanyak 42 siswa, sedangkan kelas X IPS 2 sebagai kelas kontrol sebanyak 41 siswa. Kelas kontrol menggunakan metode pembelajaran konvensional sedangkan kelas eksperimen menggunakan strategi pembelajaran aktif Team Quiz. Instrument yang digunakan dalam penelitian ini berupa angket yang terdiri dari 50 butir pernyataan. Sebelum angket tersebut disebarkan di kelas eksperimen dan kelas kontrol, terlebih dahulu harus dilakukan uji coba. Uji coba dilakukan terhadap 41 siswa yaitu siswa kelas X IPS 4. Hal ini dilakukan untuk menentukan tingkat validitas dan reliabilitas angket tersebut.

Berdasarkan hasil penelitian dengan menerapkan strategi pembelajaran aktif tipe Team Quiz dalam mata pelajaran Sejarah pada materi Peradaban Awal Dunia dapat meningkatkan keaktifan belajar siswa. Ini terlihat dari analisis data tentang keaktifan 
belajar siswa. Berdasarkan analisis data diketahui bahwa keaktifan belajar siswa kelas eksperimen lebih baik daripada keaktifan belajar siswa kelas kontrol. Hal ini terlihat dari nilai rata-rata kelas eksperimen adalah 115.95 dan nilai rata-rata kelas kontrol adalah 107.51. berdasarkan hasil perhitungan diperoleh nilai $t_{\text {hitung }}=3.47$ dan $t_{\text {tabel }}=1.98$ pada taraf kesalahan $\alpha=5 \%$ dengan $\mathrm{dk}_{1}+\mathrm{n}_{2}-2(42+41-2=81)$. Disini dapat dilihat bahwa $t_{\text {hitung }}>t_{\text {tabel }}(3.47>1.98)$ maka H0 ditolak dan Ha diterima, ini berarti penerapan strategi pembelajaran aktif tipe Team Quiz pada mata pelajaran sejarah pada sisa kelas eksprimen terlihat adanya peningkatan keaktifan belajar sejarah daripada keaktifan belajar siswa kelas kontrol yang menggunakan metode konvensional.

Pada saat pelaksanaan proses pembelajaran menggunakan strategi pembelajaran aktif tipe Team Quiz pada materi peradaban awal dunia sudah berjalan dengan baik. Semua siswa kelas eksperimen hadir dalam pembelajaran sejarah. masing-masing siswa dapat mengemukakan pendapat, memberi kiritik, masukan, dan aktif dalam kelompok dalam diskusi maupun pada saat kuis. Hal ini menunjukkan bahwa penerapan strategi Team Quiz pada pembelajaran Sejarah memberikan dampak positif serta adanya peningkatan terhadap keaktifan belajar Sejarah siswa kelas eksperimen dibandingkan keaktifan belajar siswa kelas kontrol. Dalam menerapkan strategi Team Quiz diawali dengan presentasi kelompok terlebih dahulu. Saat presentasi kelompok berlangsung terlihat setiap anggota kelompok berperan aktif dan bekerjasama dalam kelompoknya untuk memecahkan masalah diskusi, dan siswa yang lain aktif bertanya dan memberikan argumennnya sehingga proses pembalajaran sejarah berjalan dengan efektif. 
Adanya kuis kelompok (team quiz) yang dilakukan setelah selesai presentasi kelompok membuat siswa lebih memperhatikan, menyimak, bersemangat dan adanya respon yang baik dari siswa, karena apabila siswa tersebut tidak memperhatikan jalannya presentasi kelompok maka kelompoknya tidak akan aktif dalam menjawab pertanyaan kuis yang diberikan pada kelompok yang melakukan presentasi kepada kelompoknya. Sehingga dengan diterapkannya strategi Team Quiz siswa lebih tertarik dalam memperhatikan jalannya presentasi kelompok, tidak lagi menganggap remeh dan mengacuhkan jalannya presentasi kelompok.

Proses pembelajaran dengan strategi Team Quiz berhasil dalam menciptakan suasana belajar yang menyenangkan dan adanya keakraban yang timbul antara siswa dengan siswa maupun siswa dengan guru. Peneliti juga melihat dalam menerapkan strategi Team Quiz dapat menumbuhkan komunikasi yang efektif dan munculnya sikap kerjasama antar kelompok, tanggungjawab dalam menyelesaikan tugas kelompok dan berpartisipasi aktif dalam proses pembelajaran. Sebaliknya di kelas kontrol terlihat bahwa siswa kurang aktif dalam mengikuti proses pembelajaran Sejarah. Siswa hanya diam dan mendengarkan jalannya diskusi kelompok tanpa adanya respon terhadap materi yang disajikan oleh kelompok yang maju presentasi. Siswa cenderung tidak memperdulikan dan tidak memperhatikan jalannya diskusi. Sehingga proses pembelajaran Sejarah tidak berlangsung efektif.

Hal ini sesuai dengan pendekatan CBSA yang lebih menitikberatkan pada keaktifan siswa dalam proses pembelajaran. Dalam CBSA, kegiatan belajar diwujudkan dalam berbagai bentuk kegiatan, seperti mendengarkan, berdiskusi membuat sesuatu, menulis, memecahkan masalah, memberikan gagasan. Setiap kegiatan tersebut 
Historia: Jurnal Program Studi Pendidikan Sejarah

Vol 4. No 1 (2019):34-45

P-ISSN 2301-8305

E-ISSN 2599-0063

menuntut keterlibatan siswa dalam proses belajar mengajar. Pendekatan CBSA dinilai sebagai suatu sistem belajar mengajar yang menekankan keaktifan siswa secara fisik, mental, intelektual, dan emosional guna memperoleh kemampuan berupa perpaduan antara aspek kognitif, afektif, dan psikomotorik.

Pelaksanaan proses pembelajaran dititikberatkan pada keaktifan siswa dalam belajar dan keaktifan guru menciptakan lingkungan belajar yang serasi dan menantang. Penerapan CBSA dilakukan dengan cara memfungsikan seluruh potensi siswa melalui penyediaan lingkungan belajar meliputi aspek bahan pelajaran, guru, strategi pembelajaran, dan suasana kelas. Peranan guru bukan sebagai orang yang menuangkan materi pelajaran kepada siswa, melainkan bertindak sebagai fasilitator bagi.

\section{KESIMPULAN DAN SARAN}

\section{Kesimpulan}

Berdasarkan hasil dan pembahasan yang telah disajikan maka dapat diambil kesimpulan bahwa keaktifan belajar Sejarah siswa kelas eksperimen yang menggunakan strategi pembelajaran aktif tipe Team Quiz lebih baik daripada keaktifan belajar Sejarah siswa kelas kontrol yang menggunakan metode konvensional. Hal ini terbukti dengan lebih tingginya nilai rata-rata skor angket keaktifan belajar siswa kelas eksperimen yaitu 115.95 sedangkan kelas kontrol yaitu 107.51. Dari hasil perhitungan uji-t diperoleh nilai $t_{\text {hitung }}=3.47$ dan $t_{\text {tabel }}=1.98$ karena $t_{\text {hitung }}>t_{\text {tabel }}(3.47>1.98)$ maka H0 ditolak dan Ha diterima sehingga dapat disimpulkan bahwa terdapat peningkatan keaktifan belajar siswa dengan menerapan strategi pembelajaran aktif tipe Team Quiz pada siswa kelas X IPS di SMA Negeri 8 Batam tahun pelajaran 2015/2016.

\section{Saran}


Historia: Jurnal Program Studi Pendidikan Sejarah

Vol 4. No 1 (2019):34-45

P-ISSN 2301-8305

E-ISSN 2599-0063

Berdasarkan hasil penelitian dan juga penarikan kesimpulan, maka peneliti ingin memberikan saran-saran yang selanjutnya dapat digunakan oleh berbagai pihak sebagai bahan masukan yang baik guna meningkatkan keaktifan siswa dalam proses belajar mengajar antara lain:

\section{Bagi guru}

Pengajaran yang diberikan guru kepada siswa hendaknya tidak monoton, guru sebisa mungkin dapat memberikan pengajaran dengan metode yang bervariasi agar siswa tidak merasa bosan dan dapat meningkatkan semangat dan perhatian siswa dalam belajar Sejarah.

\section{Bagi siswa}

Dalam proses pembelajaran siswa hendaknya dapat lebih tertib, disiplin dan aktif dalam kegiatan belajar yang dilakukan. Siswa tidak hanya diam dan menunggu penjelasan dari guru saja melainkan siswa harus aktif mencari tambahan informasi terhadap materi pelajaran di sekolah dan bertanya terkait materi yang belum dipahami.

\section{Bagi peneliti selanjutnya}

Diharapkan penelitian selanjutnya dapat memperluas ruang lingkup penelitian ini dengan memperhatikan variabel-variabel lain yang dapat berpengaruh pada proses belajar mengajar Sejarah.

\section{DAFTAR PUSTAKA}

Anggraini, Tutik. (2012). Penerapan metode Team Quiz Dalam Proses Pembelajaran untuk Meningkatkan Hasil Belajar Matematika Kelas IV Di SD Negeri Begalon 1 Surakarta. Skripsi, Universitas Muhammadiyah Surakarta, Surakarta. Tidak diterbitkan, $\quad$ sumber tersedia di http:// 
Historia: Jurnal Program Studi Pendidikan Sejarah

Vol 4. No 1 (2019):34-45

P-ISSN 2301-8305

E-ISSN 2599-0063

eprints.ums.ac.id/19847/13/10._Naskah_Publikasi.pdf, diunduh tanggal 16 Februari 2016.

Arikunto, Suharsimi. (2010). Prosedur Penelitian. Jakarta: Rineka Cipta.

Arikunto, Suharsimi. (2013). Dasar-dasar Evaluasi Pendidikan. Jakarta: Bumi Aksara.

Aunurrahman. (2009). Belajar dan Pembelajaran. Bandung : Alfabeta.

Darini, Ririn. 2013. Sejarah untuk SMA/MA Kelas X Peminatan Ilmu-ilmu Sosial. Klaten: PT. Cempaka Putih.

Dimyati \& Mudjiono. (2009). Belajar dan Pembelajaraan. Jakarta: Rineka Cipta.

Djamarah, S. B \& Zain, A. (2013). Strategi Belajar Mengajar. Jakarta: Rineka Cipta.

Hamruni. (2012). Strategi Pembelajaran. Yogyakarta: Insan Madani.

http://miratriani.blogspot.co.id/2012/07/metode-team-quiz-dan-talking-stick_3243.html diunduh tanggal 17 februari 2016.

http://nocaou.blogspot.co.id/2013/09/pendekatan-cbsa.html?m=1 diunduh tanggal 25 September 2016

http://suaidinmath.files.wordpress.com/2014/09/5-pmp-sejin-sma-allson1juni2014.docx diunduh tanggal 25 Februari 2016.

Muzamiroh, M. L. (2013). Kupas Tuntas Kurikulum 2013. Kata Pena: Jakarta

Noor, Juliansyah. (2012). Metodologi Penelitian: Skripsi, Tesis, Disertasi, dan Karya Ilmiah. Jakarta: Kencana.

Priansa, D. J. (2015). Manajemen Peserta Didik dan Pembelajaran. Bandung: Alfabeta.

Rizkyana, Mei. (2013). Penerapan Metode Quiz Team untuk Meningkatkan Keaktifan Belajar pada Siswa Kelas X AP SMK PGRI 1 Mejobo Kudus. Skripsi, UNNES, Semarang. Tidak diterbitkan, sumber tersedia di http://Iib.unnes.ac.id/17206/1/7101408290.pdf, diunduh tanggal 17 Februari 2016.

Rumengan, Jemmy. (2009). Metodologi Penelitian dengan Menggunakan SPSS. Bandung: Citapustaka Media Perintis.

Sanjaya, Wina. (2008). Kurikulum dan Pembelajaran: Teori dan Praktik Pengembangan Kurikulun Tingkat Satuan Pendidikan (KTSP). Jakarta: Kencana. 
Historia: Jurnal Program Studi Pendidikan Sejarah

Vol 4. No 1 (2019):34-45

P-ISSN 2301-8305

E-ISSN 2599-0063

Sarah, R. F. (2013). Peningkatan Keaktifan Belajar IPS Sejarah Siswa Melalui Model Pembelajaran Index Card Match (ICM) Kelas VIII di SMP Negeri 4 Semarang. Skripsi, UNNES, Semarang. Tidak diterbitkan, sumber tersedia di http://Iib.unnes.ac.id/19279/1/3101409039.pdf, diunduh tanggal 11 Februari 2016.

Silberman, Melvin. (2013). Active Learning : 101 Cara Belajar Siswa Aktif. Bandung: Nuansa Cendekia.

Siregar, Syofian. (2013). Metode Penelitian Kuantitatif: Dilengkapi Perbandingan Perhitungan Manual \& SPSS. Jakarta: Kencana.

Slameto. (2010). Belajar dan Faktor-faktor yang Mempengaruhinya. Jakarta: Rineka Cipta.

Sudjana. (2005). Metoda Statistika. Bandung: Tarsito.

Sugiyono. (2011). Statistika Untuk Penelitian. Bandung: Alfabeta.

Sugiyono. (2013). Metode Penelitian Pendidikan Pendekatan Kuantitatif, Kualitatif dan $R \& D$. Bandung: Alfabeta.

Sutikno, Sobry. (2013). Belajar dan Pembelajaran. Lombok: Holistica.

Sutikno, Sobry. (2014). Metode \& Model-model Pembelajaran. Lombok: Holistica.

Syafril, dkk. (2012). Pengantar Pendidikan. Padang: Sukabina Press.

Warsono \& Hariyanto. (2013). Pembelajaran Aktif: Teori dan Asesmen. Bandung: PT Remaja Rosdakarya.

Zaini, Hisyam. (2011). Strategi Pembelajaran Aktif. Yogyakarta : CTSD IAIN Sunan Kalijaga. 